\title{
Utilization of the Integrated Service Application System (SIAPEL) in Civil Service Retirement Administration Services \\ (Study of Employment Policy Implementation based on Malang Regency Regional Regulation Number 5 of 2012 concerning the Implementation of Malang Regency Public Services)
}

\author{
Nurman Ramdansyah, Agus Sholahuddin, Kridawati Sadhana \\ University of Merdeka Malang
}

Indonesia

\begin{abstract}
This study aims to describe and analyze the implementation of the Integrated Service Application System (SIAPEL) policy in PNS Pension Administration Services in the Malang Regency Government; and to identify and analyze the supporting and inhibiting factors for the implementation of the Integrated Service Application System (SIAPEL) policy in the Civil Service Pension Administration Service in the Malang Regency Government. This research method is a qualitative research. The implementation of pension administration services by utilizing SIAPEL at BKPSDM in terms of the number of implementing apparatus, namely SIAPEL Operators and One Stop Service officers at BKPSDM is still limited so that it is less effective in carrying out their official duties and Increasing the competence of implementing apparatus by carrying out Technical Training for SIAPEL Operators is still very limited because the system is still updating. The supporting factor for the implementation of the SIAPEL policy is the bupati's policy on public services that must be perfected to encourage innovation in the emergence of the Siapel system. The inhibiting factor is that the development of technology in the digitalization era is considered sudden, so that technical implementers do not yet have full readiness in terms of operationalization.
\end{abstract}

Keywords: Integrated Service Application System (SIAPEL), Administration Service, Pension.

\section{INTRODUCTION}

The smooth implementation of government tasks and national development is highly dependent on the working mechanism of the state apparatus. The State Civil Apparatus is not only an element of the State apparatus, but also a public servant who lives in the midst of society and works for the benefit of the community. ASN, which is abbreviated as ASN, is aapparatus who have met the specified requirements, are appointed by the competent authority and assigned tasks in a position country, or assigned tasks countryother, and in salary based on the applicable laws and regulations. ASN is a profession for Civil Servants who are abbreviated as PNS and Government Employees with Work Agreements who work in Government Agencies and abbreviated as PPPK. The position and role of ASN in every government organization is very decisive, because it is the backbone of the government/as the implementer of public policy in carrying out national development.

It is very important to conduct a study on the use of SIAPEL in personnel services in order to accelerate personnel services, especially during the Covid-19 pandemic which enforces a flexible work schedule (working from the office/Work from Office/WFO and working from home called Work from Home/WFH). . Besides that, BKPSDM is an agency that handles and manages the field of staffing as well as education and training within the Malang Regency Government. The use of SIAPEL and SAPK in pension administration services is still a problem, so the researchers took the title "Utilization of the Integrated Service Application System (SIAPEL) in PNS Pension Administration Services (Employment Policy based on Malang Regency Regulation Number 5 of 2012 concerning the Implementation of Malang Regency Public Services)" .

This study aims to describe and analyze the implementation of the Integrated Service Application System (SIAPEL) policy in Civil Service Retirement Administration Services in the Malang Regency Government; and to identify and analyze the supporting and inhibiting factors for the implementation of the Integrated Service Application System (SIAPEL) policy in the Civil Service Retirement Administration Service in the Malang Regency Government. 


\section{LITERATURE REVIEW}

\subsection{Public Policy Theory}

Public policy is an action taken by the government in order to achieve goals and objectives for the benefit of the whole community, which is able to accommodate the values that develop in society, whether it is done or not, this understanding is in line with the opinion of Islamy (2000:20) which states that the policy The state is a series of actions that are determined and implemented or not carried out by the government which has a goal or is goal-oriented for the benefit of the whole community. The state policy can be in the form of laws and regulations that are used for the purposes, targets of programs and actions taken by the government. In making good and correct public policies, various factors must be considered, as stated by Amara Gianttya in Islamy (2001:17) argues that a policy must contain the following elements:

a. Identification of the goals to be achieved;

b. Tactics or strategies of various steps to achieve the desired goal;

c. Provision of multiple inputs to enable the actual execution of a tactic or strategy.

\subsection{Governance Concept}

Good Governance (Miftah Thoha, 2003) is governance that is run by the government, the private sector and the people in a balanced way by having a good category (good) as Loina Lalolo KP (2003) argues that the balance of the implementation of roles and functions between the state, market and society.

Based on the above understanding, good governance has the following characteristics (Bapenas, 2002):

1) Accountable, meaning that policy making and implementation must be accompanied by accountability;

2) Transparent, meaning that there must be adequate information available to the public regarding the process of making and implementing policies;

3) Responsive, meaning that in the process of making and implementing policies, it must be able to serve all stakeholders;

4) Equal and inclusive, meaning that all members of the community without exception must have opportunities in the process of making and implementing a policy;

5) Effective and efficient, meaning that policies are made and implemented by using the available resources in the best way;

6) Following the rule of law, meaning that the process of making and implementing policies requires a fair and enforceable legal framework;

7) Participative, meaning that policy making and implementation must open up space for the involvement of many factors;

8) Oriented to consensus / agreement. This means that the creation and implementation must be the result of mutual agreement between the actors involved.

\subsection{One Stop Service Concept}

One-Stop Integrated Service is defined as the activity of administering a license and non-licensing that gets delegation of authority and an agency that has the authority whose management process starts from the application stage to the stage of document issuance which is carried out in one place. The meaning is different from the definition of "One Stop Service", which is abbreviated as PTSP. In the Decree of the Minister of PAN Number 63/KEP/M.PAN/7/2003, the definition of "One-Stop Integrated Service" is a service pattern that is held in one place for various types of services that do not have a process linkage and are served through several doors, while "Services is One Door" is a service pattern that is held in one place which includes various types of services that have a related process and are served through one door.

\subsection{Service Quality Concept}

Fitzsimmons and Fitzsimmons (in Sinambela, 2006: 7) argue that there are five indicators to measure good public services, namely, first, tangibles. Namely, the provision of adequate human resources and other resources, second, reliability, namely providing services correctly and correctly, third, responsiveness, namely the desire to serve consumers quickly, fourth, assurance, namely the level of attention to ethics and morals in providing services and fifth, empathy. namely the level of willingness to know the wants and needs of consumers. 


\subsection{Service Application System in Public Organizations}

Public organizations have fundamental differences with private organizations, such as differences in service orientation, aspects of economic authority, political authority, personnel management and organizational and individual behavior (Kumorotomo, 2004: 82). Along with the increasingly complex demands of society, especially regarding the availability of information in obtaining services, information systems are not only used in private organizations, but also penetrated into public organizations. Service application systems in public organizations need to be studied because:

1) Public agencies require a computer-based service application system for the effectiveness and efficiency of work implementation

2) The rapid development of E-government

\section{RESEARCH METHODS}

\subsection{Research methods}

Research on the policy model of PNS Pension administration services through SIAPEL in the Malang Regency Government based on Malang Regency Regulation Number 5 of 2012 concerning the Implementation of Malang Regency Public Services, requires ongoing studies. The research method used to study continuously is qualitative which is carried out to generate hypotheses and analyzes descriptively through procedural and managerial according to Wahab (2008:110-120). Qualitative method is a research procedure that produces descriptive data in the form of written or spoken words and people as well as observations of behavior according to Bondan and Taylor in Moleong (2002:3).

This research uses a procedural and managerial approach to improve the effectiveness of the implementation so that the research obtains a strategy to be able to develop processes and procedures in implementing them according to stages. The implementation phase of the procedural and managerial approach includes program design, implementation, scheduling, and supervision.

\subsection{Research Focus}

Determination of focus is done because there are two specific purposes that researchers want to achieve, first setting focus to limit the study and second setting focus to fulfill the criteria of entering and removing new information from the field. In this study, the research focus is:

1) Policy implementation of the Integrated Service Application System (SIAPEL) for Pensions in Civil Service Pension Administration Services at BKPSDM:

a. Communication, which is a policy implementer's competence which is still lacking;

b. Resources, which are facilities and infrastructure in implementing SIAPEL, are still limited in their functions;

c. Disposition, which is the character of the policy implementer, does not yet have an optimal level of democracy;

d. Bureaucratic structure, which in carrying out its duties and functions is based on Standard Operating Procedures (SOP) but is still not optimal.

2) Factors supporting and inhibiting the implementation of the Integrated Service Application System (SIAPEL) policy in Civil Service Retirement Administration Services in the Malang Regency Government:

a. Internals.

b. External.

\subsection{The scope of research}

The scope of research is a limitation in conducting research. The scope of this research is the use of the Integrated Service Application System (SIAPEL) in the Civil Service Pension Administration Service based on the Malang Regency Regional Regulation Number 5 of 2012 concerning the Implementation of Malang Regency Public Services. In its application, SIAPEL for Pension Administration Services at BKPSDM is supported by the One Stop Service (PTSP) for receiving letters and personnel administration files, so that staffing services are more effective, efficient and transparent. In accordance with the duties and 
functions of the BKPSDM, the SIAPEL Pension is carried out by the Apparatus Procurement and Dismissal Sub-Sector in the Procurement, Dismissal, and Apparatus Information Sector.

\subsection{Research Sites}

Research location is a place or area where researchers conduct research on objects. In this study, the researchers took the location in Malang Regency. While the research site is a place where researchers will capture the actual state of the object to be studied in order to obtain data. In this case, the research sites are BKPSDM and civil servants who apply for pensions. The selection of this site is based on an initial survey conducted by researchers showing that the implementation of SIAPEL Pension in Personnel Services at BKPSDM has not run optimally, staffing information generated from SIAPEL has not been obtained optimally by the relevant agency, because in reality there are many factors that become obstacles such as apparatus resource capabilities, adequate facilities and infrastructure, which must be prepared to support the smooth implementation of SIAPEL. This needs to be done so that the resulting personnel information can be useful for the decision-making process and improve the quality of service, which is supported by the receipt of letters and personnel administration files at the One Stop Integrated Service.

\subsection{Data Types and Sources}

Data sources are places where important data and information are found that can support research. According to Moleong (2002:112) the main data sources in qualitative research are words and actions, the rest are additional data such as documents.

The source of the data in this study was obtained from resource persons, namely PTSP implementers who handle the administration of PNS Pension submission services. Collecting data using interview techniques using the tools are documents, qualitative notes, and notes from interviews. While the data taken is the satisfaction of pension administration services by utilizing SIAPEL against civil servants who propose retirement through the Community Satisfaction Survey with perceptions of corruption.

\subsection{Research Instruments}

The data collection instrument according to Suharsimi Arikunto (2000:134), is a tool that is selected and used by researchers in their activities in collecting to be systematic and easier. Research Instruments are tools or facilities used to collect research data, the research instruments are:

a. Researchers, to carry out observations, interviews with data sources and objects studied, besides that researchers always capture every phenomenon that occurs related to the object of research.

b. The interview guide is used as a basic framework in conducting interviews so that the interviews conducted by researchers remain focused and maintain relevance to the problems in the study.

c. Supporting devices, including tools in the form of tools for recording and recording images.

\subsection{Population and Sampling Techniques}

a. Population

According to Creswell (2008), the population is a group of individuals who have the same or relatively similar characteristics. Neuman (200), defines it as a large group of unified samples to be studied. According to the research dictionary by Drs. Komarudin, what is meant by population is: all individuals who are the source of sampling. In fact, the population is a collection of cases that need to meet certain conditions related to the research problem (Mardalis, 2004: 53). The population in this study is the BKPSDM implementer who handles the administration of civil servant pension services.

b. Sample

The sample is part of the population that will be involved in the study which is a representative part and represents the character or characteristics of the population (Neuman, 2000). Sample means sample, which is part of all individuals who are the object of research. The purpose of determining the sample is to obtain information about the object of research by observing only part of the population (Mardalis, 2004:55). So the researchers took samples who were informants, which consisted of: PTSP implementers and 11 (eleven) people who handled pension administration. With the services provided by BKPSDM implementers to civil servants who apply for retirement, it is possible to measure the level of service satisfaction through the Public Satisfaction Survey with perceptions of corruption. 
c. Sampling technique

To determine the sample size, a sampling technique is needed. reSample is part of the population that is the object of research. The technique of taking this sample uses a purposive sampling technique in which the sampling of its members or elements as well as the individuals who are members of it are selected and determined beforehand (Arikunto, 1993:113).

The use of this sampling technique has a purpose or is done intentionally, how to use this sample among the population so that the sample can represent previously known population characteristics. The use of this technique is always based on knowledge of certain characteristics that have been obtained from the previous population (Mardalis, 2004: 58).

Given that in this study it is not possible to conduct interviews and record all elements in the population, because apart from being impractical due to considerations of time, effort and cost, the research was conducted using purposive sampling, namely by taking subjects not based on strata, random or random. area but based on a specific purpose, provided that the sample is representative or representative of the population.

\subsection{Data collection technique}

Data collection is a very important step in the scientific method because the resulting data is expected to be used to solve problems, because the data must be valid by using field research methods. The techniques that will be used in data collection in this study are:

1) Observation / observation

A data collection technique by making direct observations of the object being studied in order to obtain actual data in accordance with the conditions in the field (field notes).

2) Interview/ interview

In this study, a data collection technique was used through a general guide approach to interviews, direct questions and answers between the researcher and the resource person.

3) Documentation

Data collection techniques are carried out by recording, copying or duplicating data related to the object of research.

\subsection{Data Analysis Techniques}

Data analysis is defined as the process of simplifying data in a form that is easier to read and interpret (Singarimbun and Efendi, 1989, p.263). After the data is presented in tabular form for analysis purposes, the researcher then draws conclusions from the results of the research as a whole based on specific findings in the field.

The data analysis technique used in this research is analysis using an interactive model. In this model there are three components of analysis, namely reduction, presentation of data and drawing conclusions (Miles and Huberman, 1992, p.20). Furthermore, the analysis is carried out by integrating (interactively) the three main components with the following procedure:

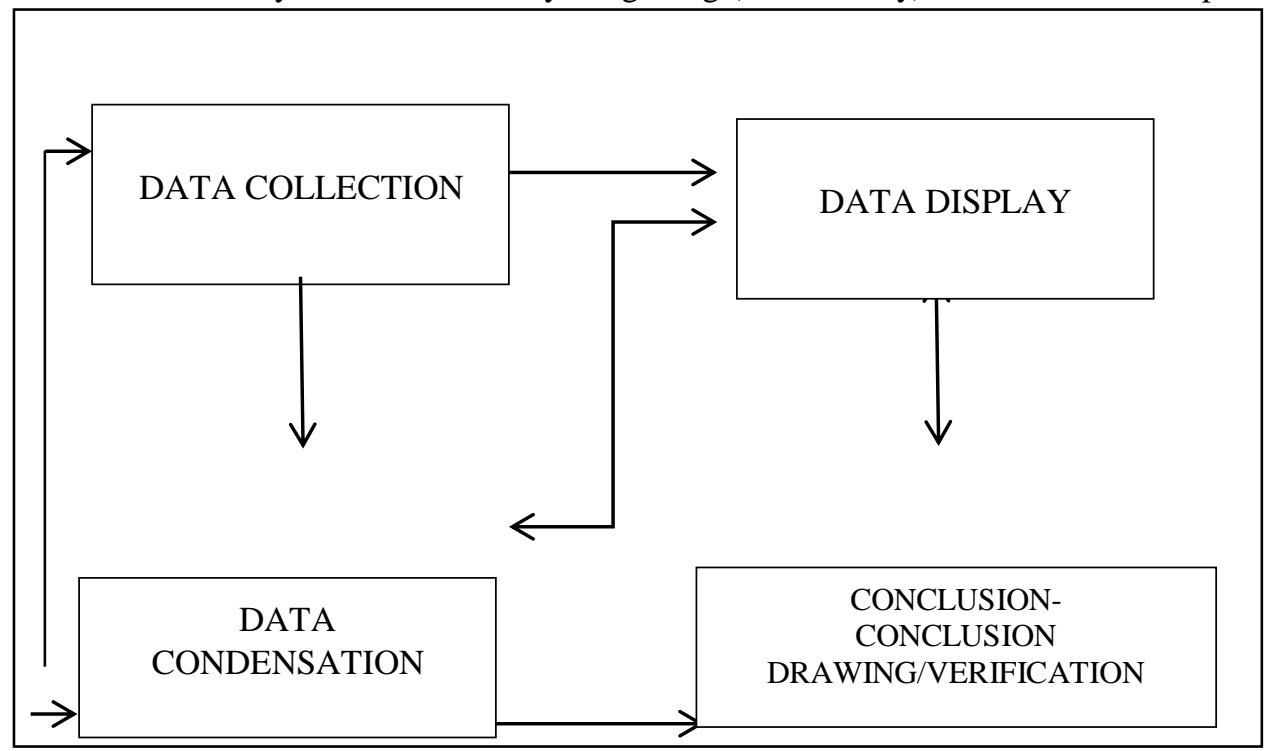

Fiogure 1 Interactive Model Data Analysis Chart 


\section{RESEARCH RESULTS AND DISCUSSION}

\subsection{Implementation of the Ready Program according to the Reality of Research}

In line with the paradigm shift in the government sector through Law Number 32 of 2004 concerning Regional Government, the institution or organizational structure of the personnel service sector underwent a fundamental change from the Personnel Section to the Regional Personnel Agency. With the change as well as the development of the BKPSDM organization, the scope of its tasks, functions and operational range will also increase. BKPSDM will have a higher role in providing services to ASN.

In line with these changes, in the field of civil servant pension administration services, stages have been carried out to improve organizational performance. As revealed by Keban (1995: 69) further states that organizational performance appraisal is very useful for assessing the quantity, quality and efficiency of services, motivating the implementing apparatus, monitoring contractors, making budget adjustments, encouraging the government to pay more attention to the needs of the people served and demanding improvement of public services. Although measuring performance only in terms of the level of efficiency and effectiveness does not necessarily describe the actual performance. If the equity indicator is increased, it may not necessarily provide the same assessment results.

\section{Communication}

The performance of BKPSDM has had an impact on improving service work patterns in the personnel sector. Because in its implementation, personnel service activities through the One Stop Integrated Service run effectively. From performance measurements carried out every quarter, BKPSDM in improving the performance of the bureaucracy and public services through increasing competence and professionalism of the apparatus has a target of 627 civil servants or $100 \%$ in 2021 . So from the predetermined target, BKPSDM is expected to achieve the target. However, to further improve the quality of excellent service, it is necessary to increase the number of skilled personnel according to the field they are engaged in, to adjust the activity budget, to support activities so that the services provided are more optimal.

So with organizational changes and the increasing number of personnel, it will not automatically improve the quality of service in the future. However, if implemented with a good managerial system, the quality of service will increase. Therefore, in order for service activities in the field of personnel to be optimal, every apparatus needs to be given the opportunity to develop integrity, loyalty and dedication so that they can carry out their duties and functions properly. In addition to the organizing apparatus, facilities and budgets must be well planned.

Based on the interviews in chapter IV, the following findings can be found:

\section{Finding 1:}

Miscommunication often occurs in online services, so that coordination is carried out that never stops, especially in subdistricts and sub-districts whose networks are often disrupted.

\section{Finding 2:}

The extension of the Personnel Board in each Service, Agency, sub-district and village often does not update, the latest rules so that information and procedures are left behind that have been created online.

Based on findings 1 and 2, it can be formulated minor proposition 1:

The implementation of policies in public services for the pension affairs of public apparatus requires continuous socialization both online and offline to be able to equalize views and movements in following the latest regulations.

\subsection{Implementing SIAPEL in One Stop Services}

\section{1) Resource}

As a supporter of the work process, the quality of human resources greatly determines the good and bad services in the field of personnel with a total of 91 civil servants consisting of 71 civil servants and 20 non civil servants. In the process of service activities, the implementing element plays a very important role in addition to other supporting factors. Based on observations made by researchers at the BKPSDM that the number of skilled personnel, level of education and basic experience possessed will play a major role in supporting work patterns and the quality of providing pension services using SIAPEL.

From the results of the interviews in chapter IV, the following findings can be formulated: 


\section{Finding 3:}

The readiness of the Ready to implement implementation apparatus has not been fully able to technically support this electronic service model.

\section{Finding 4:}

Most of the training and education of technical implementers have not been in line with the work being carried out so that they can easily overcome all obstacles.

From findings 3 and 4, it can be formulated minor proposition 2:

The implementation of the Ready is an answer to the demands of public services in a fast, easy and transparent manner, where technology has shifted the implementation of services and human life, especially to the competence of the implementers.

\section{2) Disposition and Bureaucratic Structure}

The implementation of the tasks and functions of the organization through the evaluation of the Standard Operating Procedures for the Administration of Civil Servant Pension Administration. From the results of the interviews, it is possible to make SOPs and work procedures for PNS pension services using SIAPEL at BKPSDM as follows:

a. Retirement requirements are in accordance with Government Regulation of the Republic of Indonesia Number 32 of 1979

b. Service Procedure

(1) The checklist for the administrative requirements file was not conveyed to the person concerned

(2) Submission of notification of PNS retirement is not written (in letters) but verbally, namely by telephone

(3) Make an application for a civil servant pension application according to the provisions and send it yourself to BKPSDM

(4) Files submitted to the BKPSDM are re-verified and grouped into 2 (two), namely: Pension group IV/c and above and Pension group IV/b and below

(5) Pension documents that are declared incomplete will be returned to the BKPSDM then submitted to the person concerned through the Sub-department. General Affairs and Personnel in their respective Regional Apparatuses and then reprocessed as in the initial process of submitting an application

(6) The SIAPEL Pension entry is not integrated with each Regional Apparatus so that the entry is carried out by the BKPSDM

(7) For groups IV/b and below, BKPSDM makes a cover letter addressed to the Regional Office. II BKN in Sidoarjo. Meanwhile, for groups IV/c and above, BKPSDM makes a cover letter addressed to BKN in Jakarta to be submitted and signed by the President.

(8) The completed/issued retirement decree is returned to the BKPSDM then submitted to the person concerned through the Sub-Division. General Affairs and Staffing in each Regional Apparatus.

Based on the interviews in Chapter IV, the following findings can be found:

\section{Finding 5:}

The easier it is for officers who are undergoing retirement to obtain information, it has an impact on the attitude of retirees who are increasingly critical of the services they receive and feel.

\section{Finding 6:}

Public service issues will easily become the main topic and will quickly affect the reputation of the government (policy implementers) so that dependence on information technology through networks is increasingly needed.

Based on findings 5 and 6, it can be formulated minor proposition 3:

The commitment of the power in supporting services for clarity and certainty in the development of digital devices will be able to support employee mobility so as to facilitate all activities and collaborations. 


\subsection{Supporting and inhibiting factors for the implementation of SIAPEL Utilization in Civil Service Retirement} Administration Services within the Malang Regency Government

1) Applicant

a. Received a notification by telephone, there was no notification letter from BKPSDM or from the relevant Regional Apparatus

b. The number of files that must be met

2) BKPSDM

a. For pensions of class IV/b and above or those occupying echelon II, the dismissal process must be accompanied by an MPP Decree and Technical Considerations signed by the Regent of Malang.

b. SAPK Pension cannot be integrated with SIAPEL

c. SIAPEL Pension has not been integrated with the Regional Apparatus in the Malang Regency area

d. Limited network connectivity between SAPK Pension and Central BKN

e. The limited number of personnel who are experts in the operation of SAPK and SIAPEL Pension

f. There are incomplete files in submitting a civil servant pension application

3) Regional Office II of BKN Surabaya in Sidoarjo

Handling of PNS pension proposal files based on the order in which the files are received or according to the queue number

4) Central State Civil Service Agency

Files handled from all provinces in Indonesia and the BKN itself must go through several stages. Files that have been processed will be sent collectively to be submitted and signed by the President

However, civil servant pension administration services by utilizing SIAPEL can be said to be more efficient, effective, and transparent. It is said to be efficient and effective because it can eliminate duplication of systems and data and information, minimize bureaucratic nodes, increase process standardization and decentralize authority. So that staffing services through the One Stop Integrated Service at BKPSDM can be more optimal.

1) Supporting factors

Internal

\section{Finding 7 :}

The regent's policy on public services that must be perfected encourages the emergence of the Ready-made system innovation.

External

\section{Finding 8:}

The pressure and demands from the community for public services that are always perfected will answer the community's demands about excellent service to improve the quality of public services, including the emergence of Presidential Decree 95 of 2018 concerning the obligation of public service providers to continue to innovate.

Based on internal and external findings, it can be formulated minor proposition 4:

Public service providers must be able to respond to the times, the expectations of service users are increasing and public awareness of public services is increasingly demanding the best service.

2) Obstacle factor

Internal

\section{Finding 9:}

The development of technology in the digitalization era is considered sudden so that technical implementers do not yet have full readiness in terms of operationalization. 
External

\section{Finding 10 :}

People's lives in terms of encouraging government performance are increasingly difficult to separate from technology, implementers in the field will be nervous if they are not well connected to one another and eventually become difficult to do.

Based on these internal and external factors, the minor proposition 5 can be formulated as follows:

The era of the industrial revolution where digital technology disruption is increasingly massive so that technology in digital systems, internet offtings can be used as a tool that can help and facilitate daily activities to answer the challenges of society's needs in this era.

From some of the minor propositions above, major propositions can be made as follows:

The implementation of policies on public services in the digital era requires innovations that can be effective, effective, and on target. Digital transformation is a concept of implementing the automation of various equipment with a combined system that can work together with one another.

\section{CLOSING}

\subsection{Conclusion}

Based on the description above, several conclusions can be drawn from the results of this study, related to the implementation of pension administration services by utilizing SIAPEL at BKPSDM:

1) Communication and Disposition

a. The number of implementing apparatus, namely SIAPEL Operators and One Stop Integrated Service officers at BKPSDM is still limited so that they are less effective in carrying out their official duties;

b. Improving the competence of the implementing apparatus by carrying out Technical Training for SIAPEL Operators is still very limited because the system is still being updated.

2) Standard Operating Procedures for pension administration services

a. Collecting data or administrative files for submitting a PNS Pension (entering the Retirement Age Limit/BUP) as many as 6 (six) people

The data and administrative files for the application for PNS submission that are collected and verified by the implementing apparatus of the BKPSDM are still lacking in files, so that the data received is not yet valid which causes the submission process and the issuance of the Pension Decision Letter to be not timely. Examples of lack of files are photos of civil servants who do not wear daily official attire, photographs that do not match the specified size, files that are not legalized and photocopies of promotion letters that are not complete/in order. The lack of such files will be informed directly to the sender of the file by the One Stop Integrated Service Officer.

b. Verification and validation of data or administrative files of civil servant retirement applications

The verification and validation process is hampered because the data obtained is still not valid because the files collected are not in accordance with the requirements for filing a civil servant pension administration.

c. The process of entering or inputting civil servant data entering the Retirement Age Limit/BUP in SIAPEL

The connectivity of the BKPSDM SIAPEL network to Regional Apparatuses is still limited to inputting processing proposals. And the process of inputting PNS Pension data and information is carried out by BKPSDM officers.

d. Results of data entry for civil servants who entered the Retirement Age Limit/BUP at SIAPEL

After obtaining complete data on the PNS Pension, it will be entered in SIAPEL by the SIAPEL operator in the Apparatus Procurement and Dismissal sub-division in the Procurement and Dismissal Sector, Apparatus Information. The data that has been entered in SIAPEL will become the database of civil servants entering the BUP. And the database which is the result of the data entry is the List of PNS Pension Proposals and the Pension Recipient Individual Data (DPCP) who reach the Retirement Age Limit accompanied by the PNS Pension administration file, which will then be sent to the Regional Office II of the Surabaya State Personnel Agency/Central State Personnel Agency. by BKPSDM. 
e. PNS nomination process and submission of PNS files entering the Retirement Age Limit/BUP to Regional Office II of the Surabaya State Personnel Agency/Central State Personnel Agency

1) List of Civil Servant Retirement Proposals

2) Individual Data of Prospective Retirement Recipients (DPCP) of Civil Servants who reach the Retirement Age Limit

The PNS Pension proposal process goes through several stages, as well as the submission of PNS Pension files must be sent directly by the BKPSDM to the Regional II Office of the Surabaya State Personnel Agency or the Central State Personnel Agency, so it takes quite a long time. If there is an error in the data on the list of PNS pension proposals and DPCP PNS, the proposal file still cannot be processed and will be handed back to the Regional Apparatus by the BKPSDM.

f. Issuance of PNS Retirement Decree from Regional Office II of the Surabaya State Personnel Agency/Central State Civil Service Agency

The PNS Pension Decision Letter can be issued before and/or according to the date of the Pension TMT if the application for Pension administration is in accordance with the provisions. However, because the administrative files for the PNS Pension are submitted in hardcopy and softcopy, there are still many incomplete files. The issued PNS Retirement Decree will be submitted by BKPSDM after the decision is taken at Regional Office II of the Surabaya State Personnel Agency/Central State Personnel Agency. From the list of PNS Pension Proposals that have been sent, there are still PNS whose Pension Decision Letters have not been issued due to a lack of files so they have to fulfill the file again and re-send the list of PNS Pension Proposals to be processed for the issuance of their Pension Decree.

g. Administrative settlement for PNS pension payments at Taspen

The Taspen management form must be signed by the Head of BKPSDM so that civil servants must meet the file requirements for submission in the form of a CPNS Decree up to the latest SK Rank which is legalized to BKPSDM through the Head of the General and Civil Service Subdivision from the Regional Apparatus.

\subsection{Theoretical Implications}

The implications of research theory are a direct result of the consequences of the findings of a research conducted. This research generally develops and supports existing theories, namely the policy implementation process, the policy implementation process based on George's policy implementation model. C. Edward III.

The policy implementation model with a takedown perspective developed by George Edward III (in Kridawati, 2011) calls his public policy implementation model indirect impact on implementation. In this theoretical approach there are four indicators that affect the success of implementing a policy, namely:

1) Communication.

The first indicator that affects the successful implementation of a policy is communication. According to him, communication really determines the success of achieving the goals of implementing public policies, effective implementation occurs when decision makers already know what they are going to do. Knowledge of what they will do, can work if communication goes well so that every policy decision and implementing regulation must be transmitted (communicated) to all appropriate personnel. In addition, the policies communicated must be precise, accurate, and consistent. Communication (transmission of information) is needed so that decision makers and policy implementers will be more consistent in implementing every policy that will be implemented in society,
a. Transmission
b. Clarity
c. Consistency

2) Resource

The second indicator that affects the successful implementation of a policy is resources. Resources are another important thing in implementing a policy. The resource sub-indicator consists of several elements:

a. Staff

b. Information

c. Authority

d. Facility 
3) Disposition

The third indicator that influences the success of policy implementation is disposition. Important things that need to be observed on the disposition indicator are:

a. The appointment of bureaucrats with the disposition or attitude of implementing will create real obstacles to policy implementation if the existing personnel do not implement the policies desired by the officials above them.

b. Incentive. Incentives are one of the recommended techniques to overcome the problem of the tendency of the implementers to manipulate incentives. Therefore, in general, people act according to their own interests, thus manipulating incentives by policy makers to influence the actions of policy implementers. By adding certain benefits or costs that might be a driving factor that makes policy implementers carry out orders well.

\subsection{Practical Implications}

The following are suggestions as input for improving public services at BKPSDM as follows:

1) BKPSDM needs to immediately make efforts to improve service management by innovating changes in procedures and personnel service mechanisms using Information Technology, namely by implementing a paperless staffing service system so that personnel services are more efficient, effective, and transparent towards good governance and clean governance.

2) BKPSDM makes notification of PNS pension applications based on the list of PNS pension care through electronic media and in writing before the time from the Retirement Date Commencement in the form of a notification letter to the Head of Regional Apparatus containing a list of pension names and requirements that must be met to PNS who will enter Retirement through the General Subsection and Staffing in each Regional Apparatus.

3) BKPSDM needs to increase the number of skilled apparatus resources according to their fields, especially those who handle and manage SIAPEL who have the ability as computer administrators, personnel analysts or computer operators. Study and Study Permits for Civil Servants.

4) BKPSDM needs to send a nominative list of PNS Pensions to Regional Office II of the Surabaya State Personnel Agency/Central State Personnel Agency periodically so that the issuance of the PNS Retirement Decree can be on time, i.e. before or during TMT PNS Pension.

5) BKPSDM needs to coordinate directly/indirectly with the Central State Personnel Agency in an effort to integrate the Personnel Service Application System (SAPK) with SIAPEL. And then SIAPEL is carried out online to all Regional Apparatuses in Malang Regency (BKPSDM as a vefifikator) in order to simplify and speed up the process of completing the data inputting process in SIAPEL.

6) BKPSDM needs to carry out periodic monitoring and evaluation related to the implementation of SIAPEL, both from the implementing apparatus and the mechanism or procedure for the administration of Civil Service Pension Administration. So that by utilizing SIAPEL, PNS Pension administration services can be carried out online/automatically. So it is necessary to monitor and evaluate SIAPEL as an effort to control and supervise public services as the organization's performance targets. In addition, BKPSDM is expected to be able to carry out the results of the monitoring and evaluation as a form of follow-up for the improvement of public services. With these improvements, BKPSDM can improve the quality of public services, especially personnel services.

\section{REFERENCES}

Dwiyanto, Agus, et al. 2006. Realizing Good Governance through public services, Yogyakarta: Gadjah Mada Press.

Ira, Authority. 1994. Implementation of Public Policy. Jakarta: Balai Pustaka Publisher.

Irawan, Handi. 2002. 10 Principles of Customer Satisfaction. Jakarta: PT. Elex Media Komputindo Gramedia Group.

Kumorotomo, 2004. Management Information Systems in public organizations. Yogyakarta: Gajahmada Univ.

Moleong, Lexy J. 2000. Qualitative Research Methodology. Bandung: PT Pemuda Roksadakarya.

Malang Regency Regional Regulation Number 2 of 2015 concerning Openness of Public Information in Malang Regency.

Malang Regency Regional Regulation Number 5 of 2012 concerning the Implementation of Malang Regency Public Services. 
Government Regulation Number 32 of 1979, concerning the Dismissal of Civil Servants

Government Regulation Number 96 of 2000 in conjunction with Government Regulation Number 9 of 2003 concerning the Authority, Appointment, Transfer and Dismissal of Civil Servants.

Perka BKN Number 2 of 2018, concerning Guidelines for Technical Considerations for PNS Pensions and Pensions for Giving Widows/Widowers to Civil Servants.

Perka BKN Number 20 of 2008, concerning Guidelines for the Utilization of the Personnel Service Application System.

Prijono Onny S. and Pranarka AMW. 1996. Empowerment of Policy Concepts and Implementation. Jakarta: CSIS.

Sadhana, Kridawati, 2011. The Reality of Public Policy. UM press, Malang.

Satori, Jam'an and A'an Komariah. 2009. Qualitative Research Methodology.

Singarimbun, Masri and Sofian Efendi (eds). 1998. Survey Research Methods. Jakarta: PT Pustaka LP3ES Indonesia. 